\title{
Storage and Flood Routing
}

Manual of Hydrology: Part 3. Flood-Flow Techniques

GEOLOGICAL SURVEY WATER-SUPPLY PAPER 1543-B

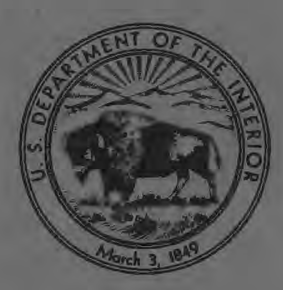




\section{Storage and Flood Routing}

By R. W. CARTER and R. G. GODFREY

Manual of Hydrology: Part 3. Flood-Flow Techniques

GEOLOGICAL SURVEY WATER-SUPPLY PAPER 1543-B

Methods and practices of the Geological Survey

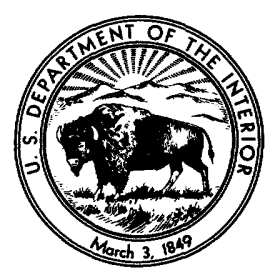




\section{UNITED STATES DEPARTMENT OF THE INTERIOR}

FRED A. SEATON, Secretary

\section{GEOLOGICAL SURVEY}

Thomas B. Nolan, Director 


\section{CONTEN'TS}

\begin{tabular}{|c|c|}
\hline \multirow{2}{*}{ Abstract } & Page \\
\hline & 81 \\
\hline Introduction & 81 \\
\hline General relation between upstream and downstream hydrographs....... & 82 \\
\hline Methods of flood routing & 85 \\
\hline Basic concepts & 85 \\
\hline Stage-storage method of flood routing & 87 \\
\hline Discharge-storage method of flood routing & 92 \\
\hline time interval & 94 \\
\hline Computation of storage volume $\ldots$ & 94 \\
\hline of the constant weighting the inflow and outflow & 96 \\
\hline Evaluation of the slope of the storage-weighted discharge relation_ & 96 \\
\hline Example of computation procedure & 97 \\
\hline Determination of storage & 98 \\
\hline Determination of constants & 98 \\
\hline oir-storage method & 102 \\
\hline rences. & 104 \\
\hline
\end{tabular}

\section{ILLUSTRATIONS}

FIGURE 31. Schematic representation of reservoir-type storage

32. Schematic representation of inflow, outflow, and storage in a

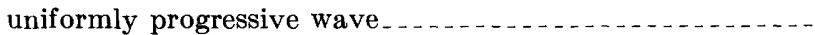

33. Schematic representation of prism and wedge storage . . . . -

34. Cochrane-Gainesville reach on Tombigbee River...........

35. Relation of mean gage height to storage in Cochrane-Gaines-

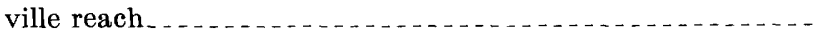

36. Relation of change in storage per foot of gage height to mean gage height for Cochrane-Gainesville reach

37. Comparison of actual and computed hydrographs for Tombigbee River at Gainesville, Ala . . . . . . . . . . . . . . .

38. Andalusia-Brooklyn reach on Conecuh River

39. Relation of storage to weighted discharge for different values of $x_{\ldots} \ldots \ldots \ldots$

40. Comparison of computed and actual hydrograph, Conecuh River near Brooklyn, Ala .........................

41. Inflow and outflow hydrographs for reservoir 


\section{TABLES}

TABLE 1. Computation of storage for Cochrane-Gainesville reach, Tombigbee River

2. Example of routing for Cochrane-Gainesville reach

3. Computation of storage for Andalusia-Brooklyn reach, Conecuh

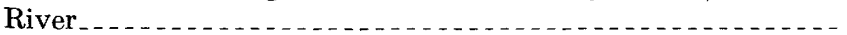

4. Computation of weighting factor $x$ for Andalusia-Brooklyn reach, Conecuh River.

Page

xample of routing for Andalusia-Brooklyn reach, Conecuh River

6. Selected values of $\frac{2 S}{\Delta t}+O$

7. Routing through a reservoir 102 


\title{
MANUAL OF HYDROLOGY: PART 3, FLOOD-FLOW TECHNIQUES
}

\section{STORAGE AND FLOOD ROUTING}

\author{
By R. W. Carter and R. G. Godfrey
}

\section{ABSTRACT}

The basic equations used in flood routing are developed from the law of continuity. In each method the assumptions are discussed to enable the user to select an appropriate technique.

In the stage-storage method the storage is related to the mean gage height in the reach under consideration. In the discharge-storage method the storage is determined from weighted values of inflow and outflow discharge. In the reservoir-storage method the storage is considered as a function of outflow discharge alone.

A detailed example is given for each method to jllustrate that particular technique.

\section{INTRODUCTION}

The storage in the reaches of stream channels is used extensively as an index of the timing and shape of flood waves at successive points along a river. Among the principal users of the technique are the Corps of Engineers who route hypothetical floods through river systems to determine the effects from proposed flood-control projects, the U.S. Weather Bureau whose forecasts of river stages are based largely on flood routing, and the operators of hydroelectric power systems who schedule their operations according to the predicted progress of a flood wave. The storage index and the techniques of flood routing may also be used to advantage in computing and evaluating streamflow records.

The primary use of these methods in the Geological Survey is in testing and improving the overall consistency of records of discharge during major floods in a river basin. The number of direct observations of discharge during such flood periods is generally limited by the short duration of the flood and the inaccessibility of certain stream sites. Through the use of flood-routing techniques, all observations of discharge and other hydrologic events in a river basin may be combined and used to evaluate the discharge hydrograph at a single site. For 
an example of a study of this type the reader is referred to WaterSupply Paper 1139 (U.S. Geological Survey, 1952).

Storage-routing techniques also are used frequently to determine the effect of artificial storage on peak discharges from small drainage basins. For economy of operation, gaging stations on many small streams are located at the outfall of small detention reservoirs impounded by dams or by highway crossings. The measured peak discharges are adjusted for the effects of artificial storage, thereby increasing their usefulness in areal studies of the frequency and magnitude of peak flow.

Another use of flood routing in hydrologic studies is in computing natural flood hydrographs for long-term gaging stations on streams where major storage reservoirs have been constructed. These computations are made to extend the time period for a single condition of basin development for use in discharge-frequency studies.

In this report, several different methods of storage routing are presented in detailed form. These methods are not new and, in general, were not originated in the Geological Survey. They are presented for the convenience of engineers engaged in hydrologic studies. A previous manual on this subject was prepared by W. B. Langbein and R. W. Carter (written communication, 1947). The methods and techniques described in this manual are the product of development in many engineering offices concerned with floods.

\section{GENERAL RELATION BETWEEN UPSTREAM AND DOWN- STREAM HYDROGRAPHS}

Flood waves are subject to two principal kinds of movementsuniformly progressive flow and reservoir action. A uniformly progressive flow designates downstream movement of a flood wave without a change in shape, which would occur only under ideal conditions in a prismatic channel in which the stage and discharge are uniquely defined at all places. Reservoir action refers to the modification of a flood wave by reservoir pondage. Flood-wave movement in natural-channel systems is probably intermediate between the two ideal conditions cited, one or the other predominating in a particular place. However, the actual behavior of the wave is sometimes obscured by the effects of local tributary inflow.

The attenuation effect of what has been called reservoir-type or pondage storage is illustrated by the performance of a detention or retarding basin - a reservoir impounded by a dam with an outlet at stream level. The outlet conduit is designed to permit the normal flows of the stream to pass unobstructed, but its capacity is exceeded by flood discharges. The impounded water creates a sensibly level pool and discharge through the conduit is related solely to the head 

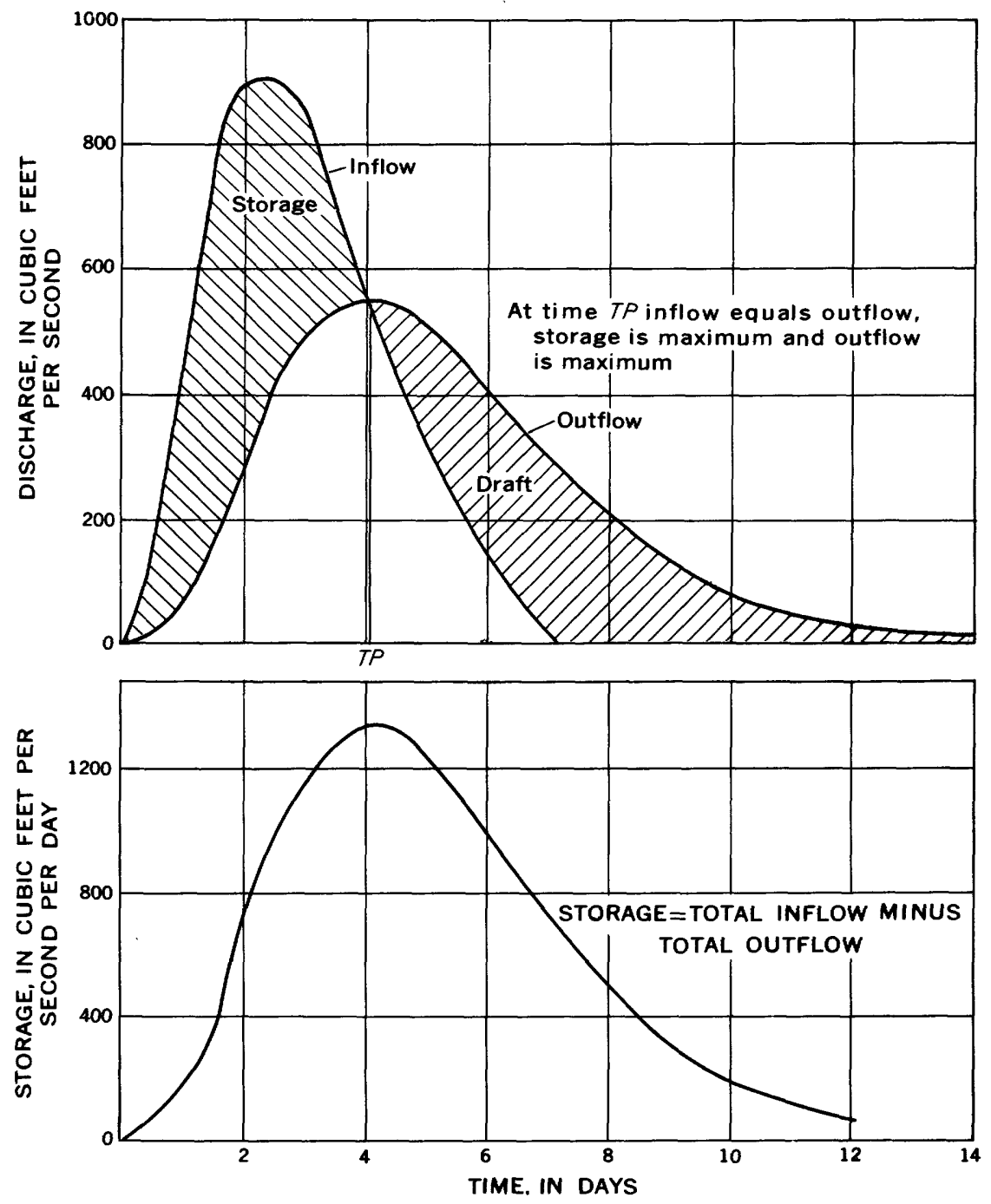

FIGtrRe 31.-Schematic representation of reservoir-type storage.

and hence to the storage. Storage in the reservoir will increase so long as inflow exceeds outflow, and is still increasing when peak inflow occurs. Figure 31 shows that storage and outflow reach a maximum $(T P)$ when inflow equals outflow, but this equality cannot occur until after inflow has receded from its peak. Therefore, reservoir or pondage storage always attenuates peak discharge.

The storage generated in a reach of channel by a uniformly progressive wave, illustrated in figure 32 , is completely different. The storage prism varies in shape and in volume. River stages and storage in a reach are conditioned by the inflow and the outflow rates. Hence, 
in the course of a flood that is controlled only by channel action, the storage increases rapidly in relation to outflow. Conversely, the storage decreases rapidly when the flood recedes. Storage is increasing when peak inflow occurs, and it continues to increase until outflow rises to equal the receding inflow. At this time the flood crest occupies a central position in the reach. At the instant of the maximum storage, the net change in storage equals zero and inflow equals outflow; the upstream stages are decreasing, the downstream stages are increasing and volume of storage in the reach at that instant is constant. After this point is passed, outflow continues to increase,
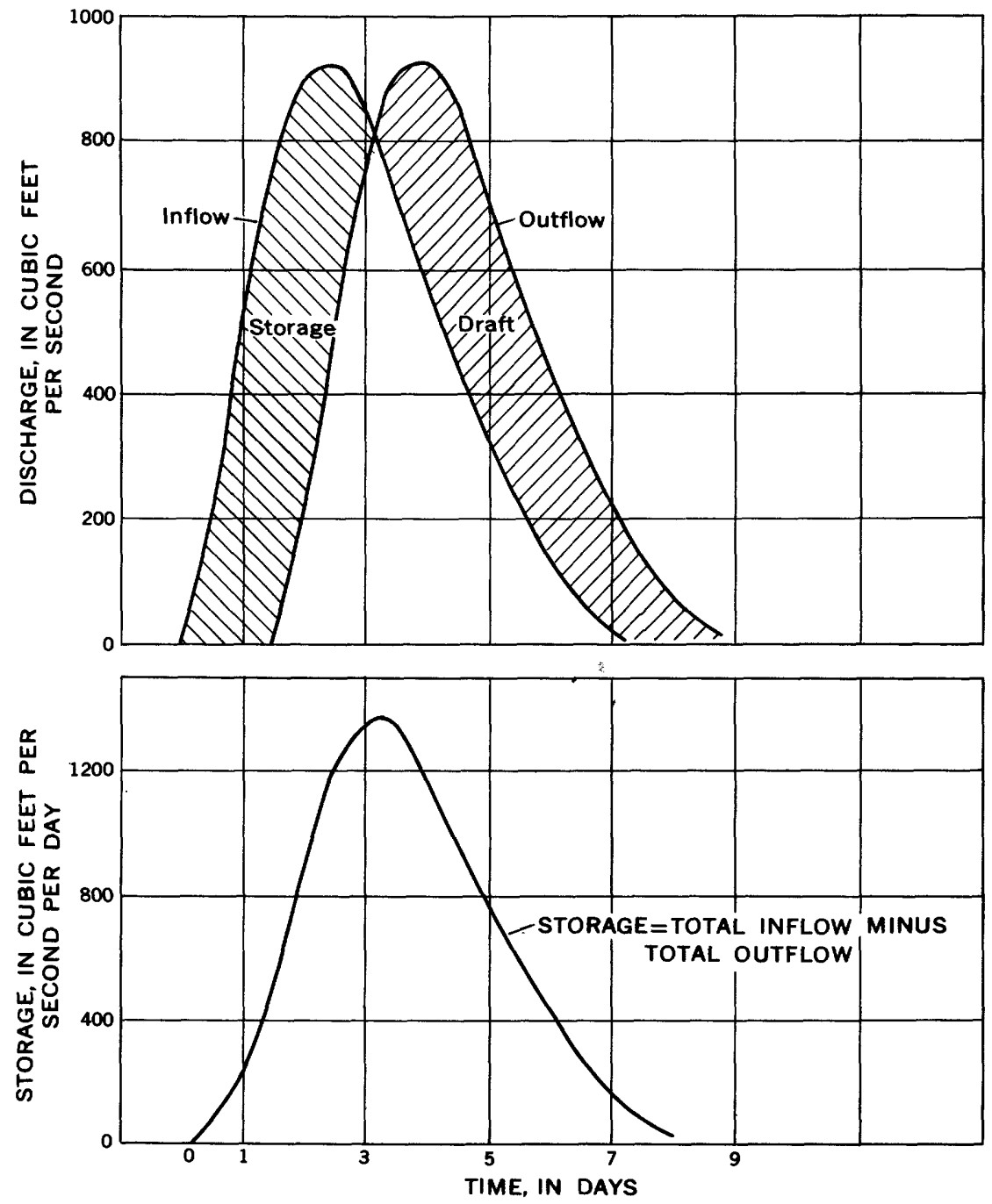

FIGURE 32.-Schematic representation of inflow, outflow, and storage in a uniformly progressive wave. 
partly at the expense of storage in the reach, until the crest passes the lower end.

Figures 31 and 32 slow the difference in the behavior of storage controlled by a fixed outlet dam and by channel action. The inflow hydrographs, total storage, and lag between centers of mass of inflow and outflow, are the same in both illustrations. In reservoir-type storage, as in figure 31 , the peak outflow is much less than the peak inflow, whereas in the uniformly progressive wave, as in figure 32 , there is no reduction in peak discharge.

River channel systems are commonly characterized by alternations of "pools" and "rapids" and of "narrows" and "intervals" which in the aggregate have much the same attenuating effect as reservoir storage. However, where the cross section and bottom slope are virtually uniform, little or no attenuation due to storage can be expected. The action of storage must not be confused with the attenuating effect of the desynchronized timing of tributary and mainstream flood peaks.

\section{METHODS OF FLOOD ROUTING}

\section{BASIC CONCEPTS}

Many different methods are used to route flood waves through river reaches. All these methods are based on the law of continuitythe volume of water that is discharged from a reach during any interval must equal the volume of inflow during the interval plus or minus any increment in stored water during the period. In equation form it becomes:

$$
\bar{O}=\bar{I}-\frac{\Delta S}{\Delta t}
$$

where $\bar{O}=$ mean outflow during routing period $\Delta t$

$\bar{I}=$ mean inflow during routing period $\Delta t$

$\Delta S=$ net change in storage during routing period $\Delta t$

Equation (1) is general. A modification frequently used is:

$$
\frac{\Delta t\left(O_{1}+O_{2}\right)}{2}=\frac{\Delta t\left(I_{1}+I_{2}\right)}{2}-\left(S_{2}-S_{1}\right)
$$

where $O, I, S$ and $\Delta t$ are as before, and the subscripts identify the beginning and ending of routing period $\Delta t$. The assumption that mean discharge is equal to the simple arithmetic average of the flows at the end points of the interval can be justified if the period is equal to, or less than, the time of travel through the reach and no abrupt changes in flow occur during the routing period. 
Two problems arise in using the storage equation in a particular reach. The first is to express the storage volume in terms of some practical index and the second is to solve equation (2) for $O_{2}$. The equation can be readily solved by graphical or analytical methods. The exact nature of the solution depends on the method used to determine the storage in the reach.

Expressing the storage volume in terms of some practical index is much more difficult, but it is extremely important because the

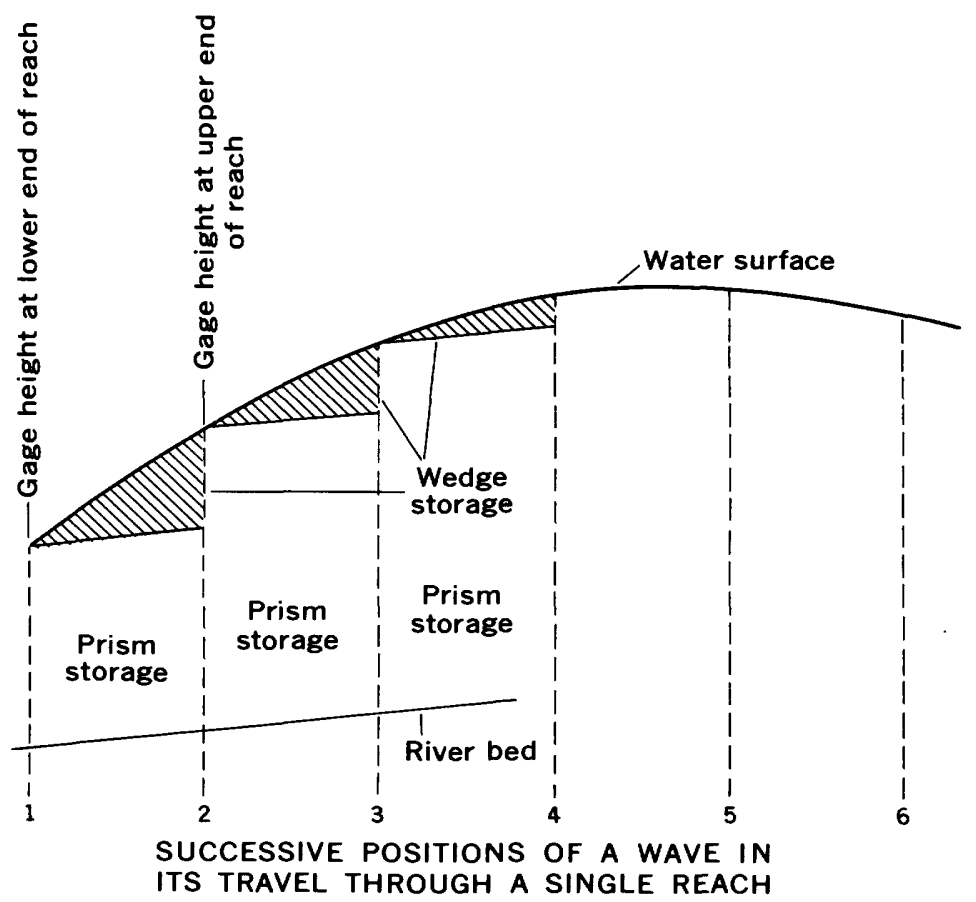

FigURE 33.--Schematic representation of prism and wedge storage.

accuracy of flood routing depends on the closeness with which the storage volume can be approximated. Assume that the reach in figure 33 represents successive positions of a wave traveling through a single reach. One element of storage commonly called "prism storage" may be easily defined in terms of stage or discharge at the downstream station. The simpler routing methods attempt to use this approximation alone, neglecting a second important volume of "wedge storage" which is superimposed on the prism. Wedge storage is a secondary approximation, but it is much more difficult to define in terms of a simple index because of the variety of shapes of the wedges. However, a routing method that ignores wedge storage is subject to serious error except in most unusual conditions. 
The storage in a reach may be determined by direct measurement from detailed maps or channel cross sections, as if computing reservoir or earthwork volumes. This approach is laborious and data are rarely adequate. Except where stage records are available during the flood to be routed, it would be necessary to compute several backwater curves defining the water-surface profile under various conditions of unsteady flow.

The method most often used is to compute the volume of storage by comparing the actual flood hydrographs. The volume of water in storage at any instant exclusive of intervening inflow between the stations is equal to the accumulated difference between inflow and outflow.

\section{STAGE-STORAGE METHOD OF FLOOD ROUTING}

The simplest method of flood routing defines the storage in terms of the mean gage height in the reach. Thus a gage-height record for both ends of the reach must be available if the flood is to be routed. The necessary stage-storage relation is generally defined on the basis of past flood-discharge records; although in certain reaches it may be defined from topographic data. Areal photographs of rivers in flood are also valuable in defining this relation. Because storage is directly related to stage, $\bar{A} \Delta h$ may be substituted in equation (1) for $\Delta S$

$$
\begin{aligned}
& \bar{O}=\bar{I}-\frac{\Delta S}{\Delta t} \\
& \bar{O}=\bar{I}-\bar{A} \frac{\Delta h}{\Delta t}
\end{aligned}
$$

where $\bar{A}=$ average area of water surface in the reach during time $\Delta t$ and $\Delta h=$ average change in water surface elevation in the reach in time $\Delta t$.

In equation (3), the value of $\bar{I}$ is obtained from the given inflow hydrograph and from the value $\frac{\Delta h}{\Delta t}$ which is obtained from the stage record. The water-surface area at a given stage is the slope of the stage-storage curve and may be easily computed from a stage-storage table, since it is the "first difference." Hence the slope or first difference is a function of the mean stage in the reach. As mentioned previously, areal photographs made during record floods can be used to construct or extend a stage-water surface relation. The outflow may be computed from the mean stage, the rate of change of stage, and the inflow.

As an example, the method is applied to the Cochrane-Gainesville reach on the Tombigbee River in Alabama. This reach, as shown 


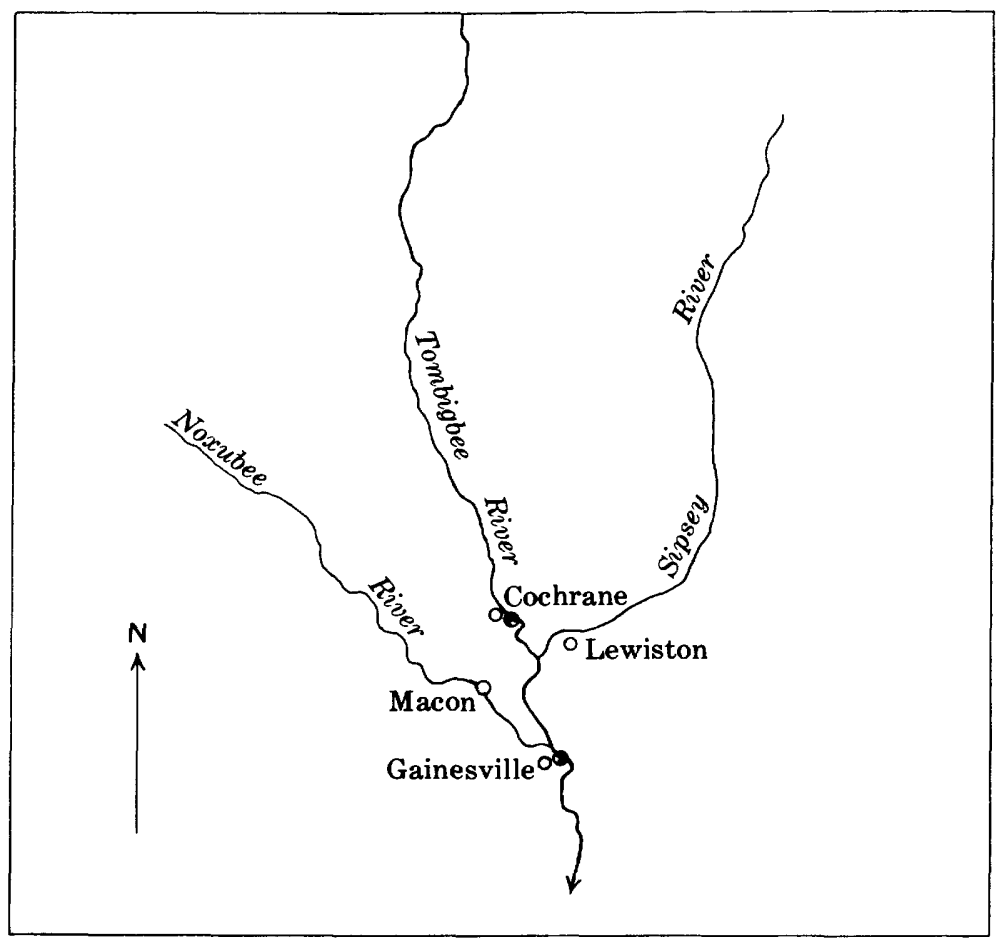

Firure 34.-Cochrane-Gainesville reach on Tombigbee River.

in figure 34, is about 25 miles long and the flow from the main tributaries entering the reach is measured. Records for the flood of July 1940 were used to define the stage-storage relation. The small amount of unmeasured inflow was estimated by increasing the flow of the measured tributaries by the drainage-area ratio. In table 1 , columns 2,3 , and 6 show the several components of inflow, and column 7 shows the total inflow. Listed in columns 8 and 9 are the accumulated inflow and the accumulated outflow. The difference in accumulated inflow and accumulated outflow, which is the total storage in the reach at the end of the selected time interval, is shown in column 10 . The storage is represented by water within the channel, on the river flood plain, in riverbank voids, and in contiguous swamps which are affected hy river levels.

The mean stage shown in column 11 of table 1 is the mean of the midnight gage heights at each end of the reach. Intermediate stage records in the reach may be included in this average if available. The mean stage and storage in the reach at the time of the mean are plotted in figure 35 . 


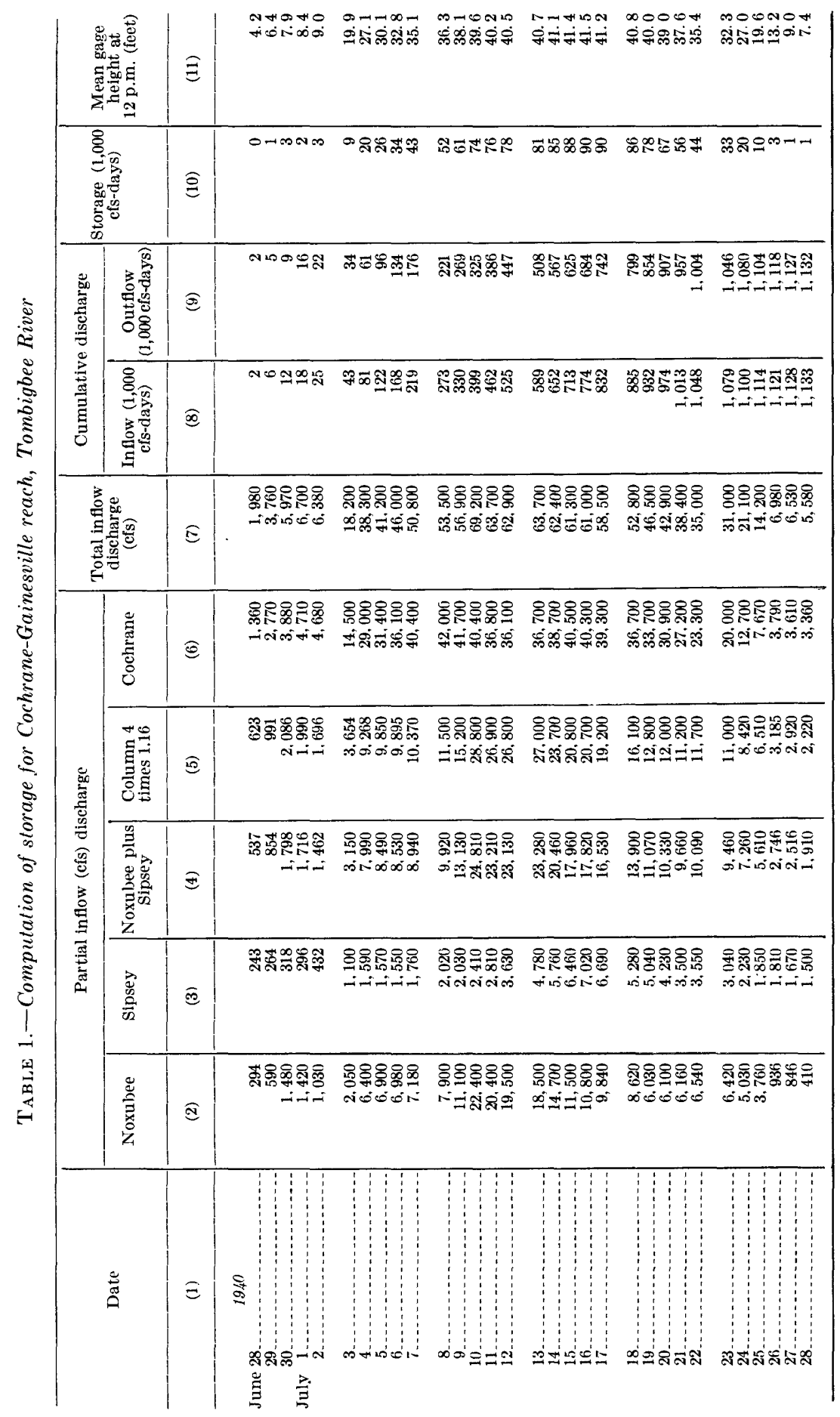




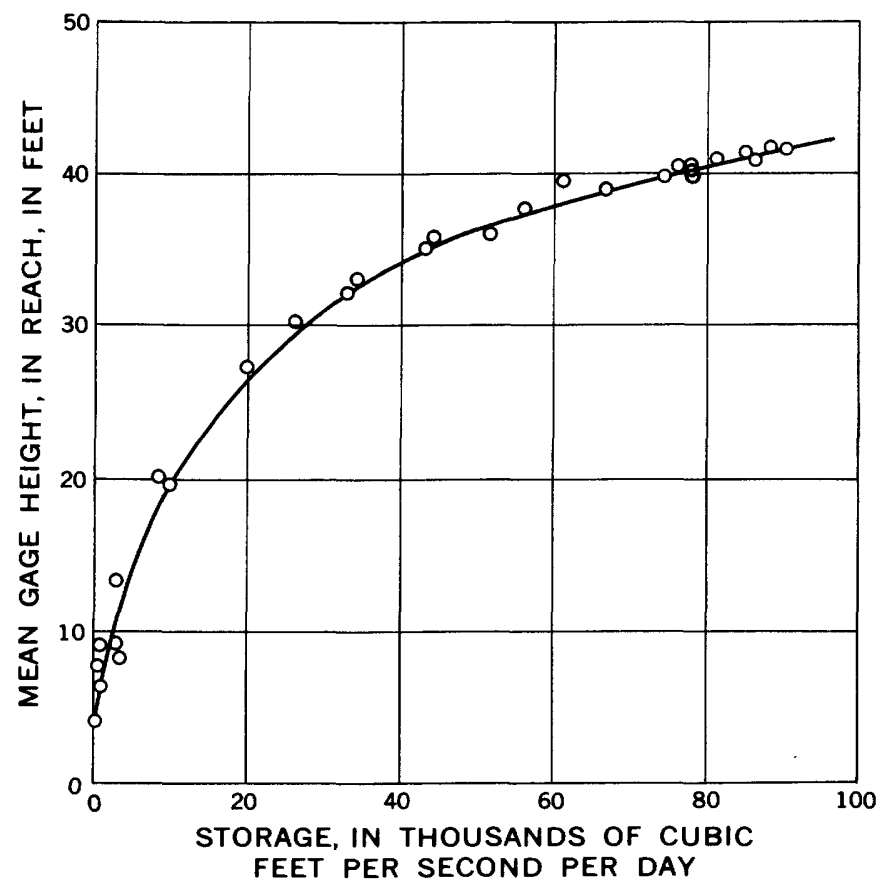

Fig URE 35.-Relation of mean gage height to storage in Cochrane-Gainesville reach.

The slope of the stage-storage curve, $\Delta s: \Delta h$, is shown plotted against the mean stage in figure 36 .

The above operation should be plotted for several floods, and an average stage-storage relation adopted. Major differences for one or more floods indicate that backwater conditions may exist or that there are errors in ratings or stage data.

The treatment of the above reach is simplified somewhat, because the storage volume is treated as a function of the straight average of the stage at each end of the reach. In reaches where a large percentage of the storage volume is near one end of the reach, the stages generally have to be weighted. Records from gages on the tributaries should be given some weight in determining the mean stage in the reach. These weights may be assigned from a knowledge of the physical characteristics of the channel or may be determined by trial and error.

'To test the stage-storage relation, the outflow hydrograph is computed from the inflow hydrograph and from the record of stage at both ends of the reach (table 2). Column 2 lists the daily mean gage height in the reach, which is obtained by averaging the observed mean daily stages at both ends of the reach. The change in storage per foot of gage height is listed in column 3 . This change is equivalent to the 


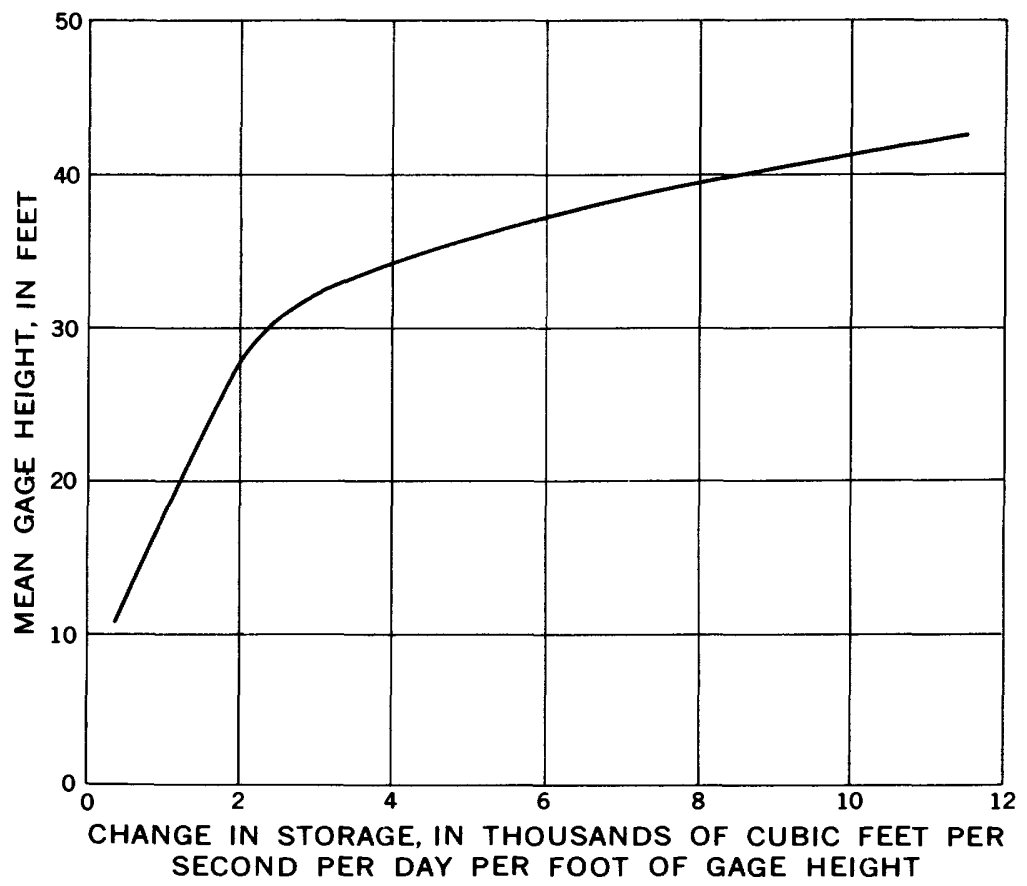

FigURE 36.-Relation of change in storage per foot of gage height to mean gage height for CochraneGainesville reach.

surface area (see equation 3) and is the abscissa of figure 36 associated with the ordinate which is the mean stage from column 2 . Listed in column 4 is the change in stage in the reach during the time interval selected, which is 1 day in this example. The product of the change in storage per foot of stage (column 3) and the stage per day (column 4) is shown in column 5. The outflow which is listed in column 7 is equal to the inflow minus the change in storage. A comparison of the computed and the actual outflow is shown in figure 37.

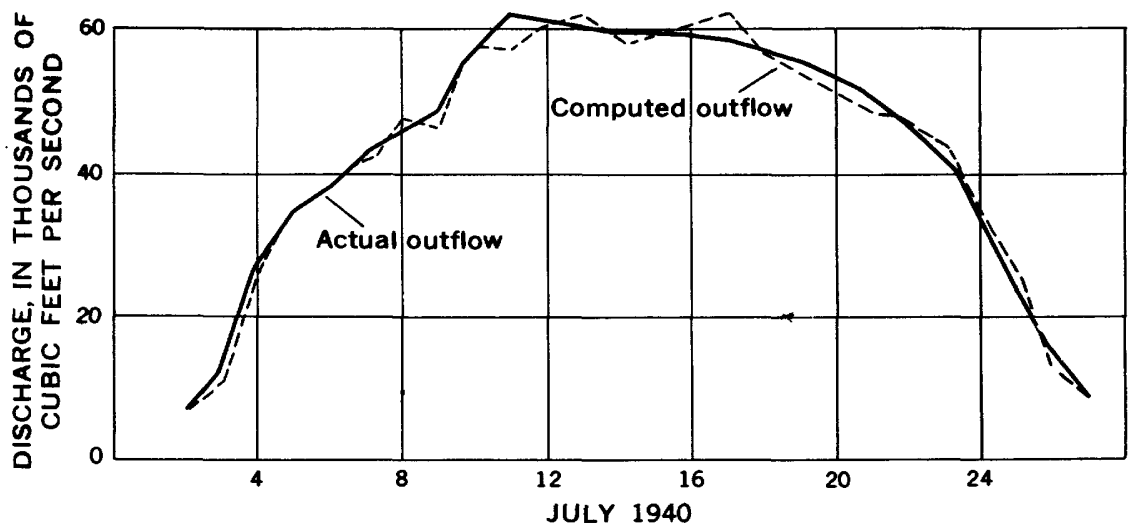

FIGURE 37.-Comparison of actual and computed hydrographs for Tombigbee River at Gainesville, Ala. 
TABLE 2.-Example of routing for Cochrane-Gainesville reach

\begin{tabular}{|c|c|c|c|c|c|c|c|c|}
\hline \multirow{2}{*}{\multicolumn{2}{|c|}{ Date }} & \multirow{2}{*}{$\begin{array}{l}\text { Mean } \\
\text { daily gage } \\
\text { height }(h) \\
\quad(\text { feet })\end{array}$} & \multirow{2}{*}{$\begin{array}{c}\frac{\Delta S}{\Delta h} \\
(1,000 \text { cfs- } \\
\text { days })\end{array}$} & \multirow{2}{*}{$\begin{array}{c}\frac{\Delta h}{\Delta t} \\
\text { (feet per } \\
\text { day) }\end{array}$} & \multirow{2}{*}{$\underset{\text { (cfs-days) }}{\frac{\Delta S}{\Delta t}}$} & \multirow{2}{*}{$\begin{array}{c}\text { Total } \\
\text { inflow } \\
\text { (cfs) }\end{array}$} & \multicolumn{2}{|c|}{ Outflow (cfs) } \\
\hline & & & & & & & Computed & Actual \\
\hline & (1) & (2) & (3) & (4) & (5) & (6) & (7) & (8) \\
\hline July & $\begin{array}{c}1940 \\
2 \\
3 \\
4 \\
5\end{array}$ & $\begin{array}{r}8.3 \\
14.1 \\
25.1 \\
28.7\end{array}$ & $\begin{array}{l}0.2 \\
.7 \\
1.8 \\
2.1\end{array}$ & $\begin{array}{r}+0.6 \\
+10.9 \\
+7.2 \\
+3.0\end{array}$ & $\begin{array}{r}+120 \\
+7,630 \\
+13,000 \\
+6,300\end{array}$ & $\begin{array}{r}6,380 \\
18,200 \\
38.300 \\
41,200\end{array}$ & $\begin{array}{r}6,260 \\
10,600 \\
25,300 \\
34,900\end{array}$ & $\begin{array}{r}6,160 \\
12,200 \\
27,100 \\
34,400\end{array}$ \\
\hline & $\begin{array}{r}6 \\
7 \\
8 \\
9 \\
9\end{array}$ & $\begin{array}{l}31.4 \\
34.1 \\
35.7 \\
37.1 \\
38.9\end{array}$ & $\begin{array}{l}2.8 \\
4.0 \\
4.9 \\
6.0 \\
7.7\end{array}$ & $\begin{array}{l}+2.7 \\
+2.3 \\
+1.2 \\
+1.8 \\
+1.5\end{array}$ & $\begin{array}{r}+7,560 \\
+9,200 \\
+5,880 \\
+10,800 \\
+11,600\end{array}$ & $\begin{array}{l}46,000 \\
50,800 \\
53,500 \\
56,900 \\
69,200\end{array}$ & $\begin{array}{l}38,400 \\
41,600 \\
47,600 \\
46,100 \\
57,600\end{array}$ & $\begin{array}{l}37,900 \\
42,000 \\
45,200 \\
48,100 \\
55,700\end{array}$ \\
\hline & $\begin{array}{l}11 \\
12 \\
13 \\
15\end{array}$ & $\begin{array}{l}40.0 \\
40.4 \\
40.6 \\
40.9 \\
41.2\end{array}$ & $\begin{array}{l}8.6 \\
9.1 \\
9.2 \\
9.5 \\
9.9\end{array}$ & $\begin{array}{l}+.80 \\
+.30 \\
+.20 \\
+.40 \\
+.30\end{array}$ & $\begin{array}{l}+6,880 \\
+2,730 \\
+1,840 \\
+3,800 \\
+2,970\end{array}$ & $\begin{array}{l}63,700 \\
62,900 \\
63,700 \\
62,400 \\
61,300\end{array}$ & $\begin{array}{l}56,800 \\
60,200 \\
61,900 \\
58,600 \\
58,300\end{array}$ & $\begin{array}{l}61,700 \\
61,000 \\
60,100 \\
59,300 \\
58,600\end{array}$ \\
\hline & $\begin{array}{l}16 \\
17 \\
18 \\
19\end{array}$ & $\begin{array}{l}41.4 \\
41.4 \\
41.0 \\
40.4 \\
39.6\end{array}$ & $\begin{array}{r}10.1 \\
10.1 \\
9.6 \\
9.1 \\
8.2\end{array}$ & $\begin{array}{r}+.10 \\
-.30 \\
-.40 \\
-.80 \\
-1.00\end{array}$ & $\begin{array}{l}+1,010 \\
-3,030 \\
-3,840 \\
-7,280 \\
-8,200\end{array}$ & $\begin{array}{l}61,000 \\
58,500 \\
52,800 \\
46,500 \\
42,900\end{array}$ & $\begin{array}{l}60,000 \\
61,500 \\
56,600 \\
53,800 \\
51,100\end{array}$ & $\begin{array}{l}58,200 \\
58,100 \\
56,900 \\
55,100 \\
52,900\end{array}$ \\
\hline & $\begin{array}{l}21 \\
22 \\
23 \\
24 \\
25 \\
26 \\
27\end{array}$ & $\begin{array}{l}38.3 \\
36.6 \\
34.0 \\
29.8 \\
23.3 \\
16.3 \\
10.3\end{array}$ & $\begin{array}{l}7.1 \\
5.6 \\
3.9 \\
2.4 \\
1.6 \\
.9 \\
.4\end{array}$ & $\begin{array}{l}-1.4 \\
-2.2 \\
-3.1 \\
-5.3 \\
-7.4 \\
-6.4 \\
-4.2\end{array}$ & $\begin{array}{r}-9,940 \\
-12,300 \\
-12,100 \\
-12,700 \\
-11,800 \\
-5,760 \\
-1,680\end{array}$ & $\begin{array}{r}38,400 \\
35,000 \\
31,000 \\
21,100 \\
14,200 \\
6,980 \\
6,530\end{array}$ & $\begin{array}{r}48,300 \\
47,300 \\
43,100 \\
33,800 \\
26,000 \\
12,700 \\
8,210\end{array}$ & $\begin{array}{r}50,200 \\
46,900 \\
41,800 \\
34,300 \\
23,800 \\
14,700 \\
8,280\end{array}$ \\
\hline
\end{tabular}

\section{DISCHARGE-STORAGE METHOD OF FLOOD ROUTING}

Most methods of flood routing now in use define the storage volume in terms of the inflow and the outflow rather than the stage. The simplest, but least accurate, routing procedures define the reach storage in terms of the outflow only. If the storage in the reach is plotted against the outflow, an irregular loop is developed rather than a single-valued graph. The loop reflects the influence of wedge storage. A much more satisfactory definition of storage was introduced by McCarthy (written communication, 1938) who used both the inflow and the outflow rates, to express storage as a function of the weighted mean flow through the reach, as follows:

Storage $=K[x I+(1-x) O]$

$I=$ inflow rate at a given time

$O=$ outflow rate at a given time

$K=$ slope of storage-weighted discharge relation and has the dimension of time

$x=$ a dimensionless constant which weights the inflow and outflow.

This method, which is known as the Muskingum method, assumes that the water-surface profile is uniform and unbroken between the 
upstream and downstream points on the reach, that the stage and discharge are uniquely defined at these two places, and that $K$ and $x$ are sensibly constant throughout the range in stage experienced by the flood wave.

The factor $x$ (equation 4) is chosen so that the indicated storage volume is the same whether the stage is rising or falling. For spillway discharges from a reservoir, $x$ may be shown to be zero, because the reservoir stage and hence the storage are uniquely defined by the outflow; hence, the rate of inflow has a negligible influence on the storage in the reservoir at any time. For uniformly progressive flow, $x$ equals 0.50 , and both the inflow and the outflow are equal in weight. In this wave no change in shape occurs and the peak discharge remains unaffected. Thus, the value of $x$ will range from 0 to 0.50 with a value of 0.25 as average for river reaches. No way is known for determining the value of $x$ from the hydraulic characteristics of a channel system in the absence of discharge records.

The factor $K$ has the dimension of time and is the slope of the storage-weighted discharge relation, which in most flood problems approaches a straight line. Analysis of many flood waves indicates that the time required for the center of mass of the flood wave to pass from the upstream end of the reach to the downstream end is equal to the factor $K$. The time between peaks only approximates the factor $K$. Ordinarily, the value of $K$ can be determined with much greater ease and certainty than that of $x$. Equations (2) and (4) may be combined into:

$$
K=\frac{\Delta t \frac{I_{2}+I_{1}}{2}-\frac{O_{2}+O_{1}}{2}}{x\left(I_{2}-I_{1}\right)+(1-x)\left(O_{2}-O_{1}\right)}
$$

or

$$
O_{2}=-\frac{(K x-0.5 \Delta t)}{(K-K x+0.5 \Delta t)} I_{2}+\frac{(K x+0.5 \Delta t)}{(K-\bar{K} x+0.5 \Delta t)} I_{1}+\frac{(K-K x-0.5 \Delta t)}{(K-K x+0.5 \Delta t)} O_{1}
$$

or simplified as

$$
O_{2}=C_{0} I_{2}+C_{1} I_{1}+C_{2} O_{1}
$$

where $x$ and $K$ have the same meaning as in equation 4 and:

$\Delta t=$ time unit of computation in fractions of a day

$I_{1}, I_{2}=$ total instantaneous inflow in cubic feet per second to a reach at the beginning of successive time units $(\Delta t)$.

$O_{1}, O_{2}=$ instantaneous outflow in cubic feet per second at the beginning of successive time units $(\Delta t)$

Note: Instantaneous values at the beginning of successive time units are used to derive the values of $x$ and $K$. Average values of discharge for the successive time intervals may be used in applying equation (7) to a set of data. 
The numerator of equation (5) is the storage increment, which is equal to the inflow minus the outflow in cubic feet per second days, whereas the denominator is the corresponding weighted-flow increment in cubic feet per second. Equation (6) gives $O_{2}$ in terms of 3 "routing coefficients" and 3 known discharges: $I_{1}, I_{2}$, and $O_{1}$. The routing coefficients may be computed from known values of $x$ and $K$. Equation (7) reduces the routing procedure by the Muskingum method to tabular multiplication and addition.

\section{SELECTION OF TIME INTERVAL}

The time increment, $\Delta t$, between successive values of inflow or outflow should be greater than $2 K x$ to avoid negative values of $C_{0}$. For some reaches, a value of $\Delta t$ greater than $2 K x$ will be too long to define the hydrograph adequately. In such reaches, trial routings should be made, using different values of $x$ through $n$ subreaches of travel time, $K_{s}=\Delta t$, such that $n K_{s}$ is equal to the value of $K$ for the entire reach. The value of $x$ which satisfactorily reproduces the outflow hydrograph would then be used in subsequent routings through the subreaches.

\section{COMPUTATION OF STORAGE VOLUME}

The storage volume is computed from equation (1) and from a record of the inflow and outflow hydrograph. Starting at a time when the inflow and outflow are about equal, that is, where both are equal to base flow, successive values of inflow and outflow are cumulated. If the inflow is from several sources such as main stem, tributary, or local, then the combination of these is used as the inflow. Local inflow from an ungaged area may be estimated from rainfall , records or may be estimated on the basis of the flow from a drainage area of similar size in the region. A check should be made to determine whether the measured inflow and outflow volumes and the estimated unmeasured volume are in balance. Minor adjustments may be made to the estimated unmeasured inflow, but if major adjustments seem necessary, possible errors in the main stream discharge records should be investigated. This may be done by choosing additional reaches above and below the main reach, and computing the storage volumes for these reaches for the same floods. It should then be apparent whether either of the main stream records is in error, and if so, which one. The difference between the cumulated inflow and the cumulated outflow represents the volume of storage in the reach at that time. An example of the computation procedure is given in columns 2 to 6 of table 3 . 
STORAGE AND FLOOD ROUTING

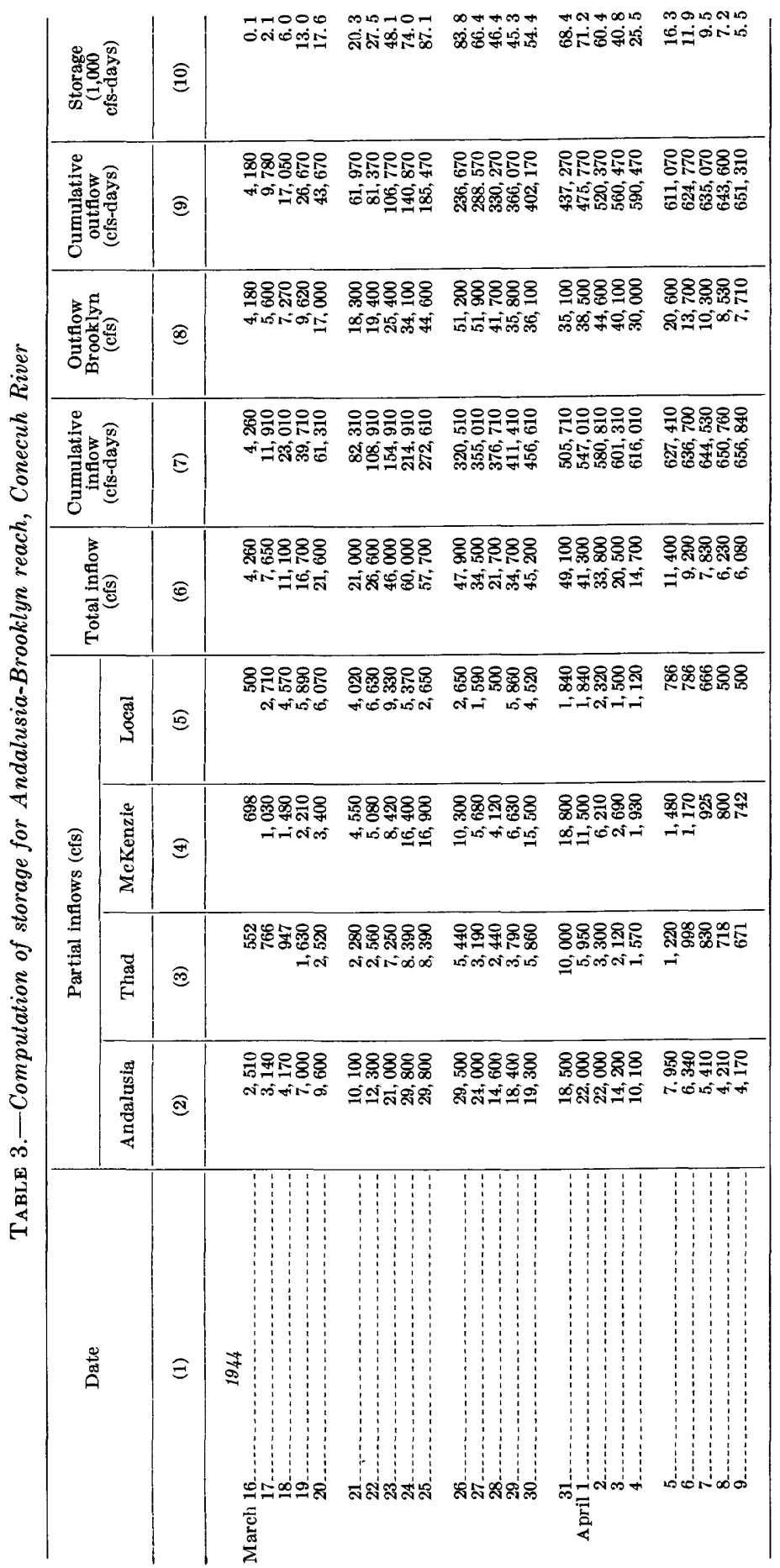


EVALUATION OF THE CONSTANT WEIGHTING THE INFLOW AND OUTFLOW

The value of $x$ for a reach is determined by a trial and error procedure. A value of $x$ is assumed and the weighted outflow-inflow discharge is computed. The weighted discharge is then plotted against the corresponding volume of storage in the reach. If the correct value of $x$ has been chosen, the storage loop should close and the plot usually approximates a straight line through the medium and high discharge range. An example of the procedure is given in table 4 and in figure 39 and will be discussed subsequently.

The value of $x$ ranges from 0 for reservoir-type storage to 0.5 for uniformly progressive flow. For natural stream channels, a common value of $x$ is 0.25 . In determining the value of $x$, great accuracy is not required because the method is relatively insensitive to the value of this coefficient.

\section{EVALUATION OF THE SLOPE OF THE STORAGE-WEIGHTED DISCHARGE} RELATION

The coefficient $K$ has the dimension of time and is the slope of the weighted-discharge storage plot described in the preceding section. The value of $K$ thus determined is the average $K$ for the reach, but if tributaries enter the reach, probably not all the inflow will rise and fall simultaneously. In such streams the storage will be influenced by the variation in inflow and a more accurate evaluation of its effect can be made by separately routing each inflow from its point of entry into the reach to the lower end of the reach. To accomplish this, it is necessary to determine individual coefficients for each component of the flow. This may be approximated by the following equations:

$$
K_{m}=\frac{\left(Q_{c}\right)}{\left(Q_{c} M\right)} K
$$

and

$$
K_{c}=M K_{m}
$$

where $K$ =average $K$ for the reach in units of days

$K_{m}=K$ per mile

$K_{c}=$ individual $K$ for separate routing of inflows

$Q_{c}=$ total inflow at one point during a given flood

$M=$ distance in miles from point of inflow to lower end of reach.

When determining the value of $K$ for several reaches of the main stem of a river, a plot of $K$ and the length of the reach is useful in determining the value of $K$ for subreaches. 
The time interval represented by $K$ is equivalent to the time required for an elemental discharge wave to traverse the routing reach. In the absence of complete discharge records, the value of $K$ for natural stream channels may be approximated by dividing the length of the reach by the mean velocity in the channel and a coefficient, $C$, that varies with the shape of the channel:

Wide rectangular

1. 67

Wide parabolic

1. 44

Triangular

1. 33

The value of $K$ in natural channels is also about equal to the time interval between the peak flow at successive points along the channel.

\section{EXAMPLE OF COMPUTATION PROCEDURE}

The computation of routing coefficients for a reach on the Conecuh River in Alabama is presented as an example. This reach is composed of the Conecuh River from Andalusia to Brooklyn, Pigeon Creek from Thad to its mouth, and Sepulga River from McKenzie, to its mouth (see fig. 38). The inflow at Andalusia, Thad, and McKenzie, and the outflow at Brooklyn are gaged. All other inter-

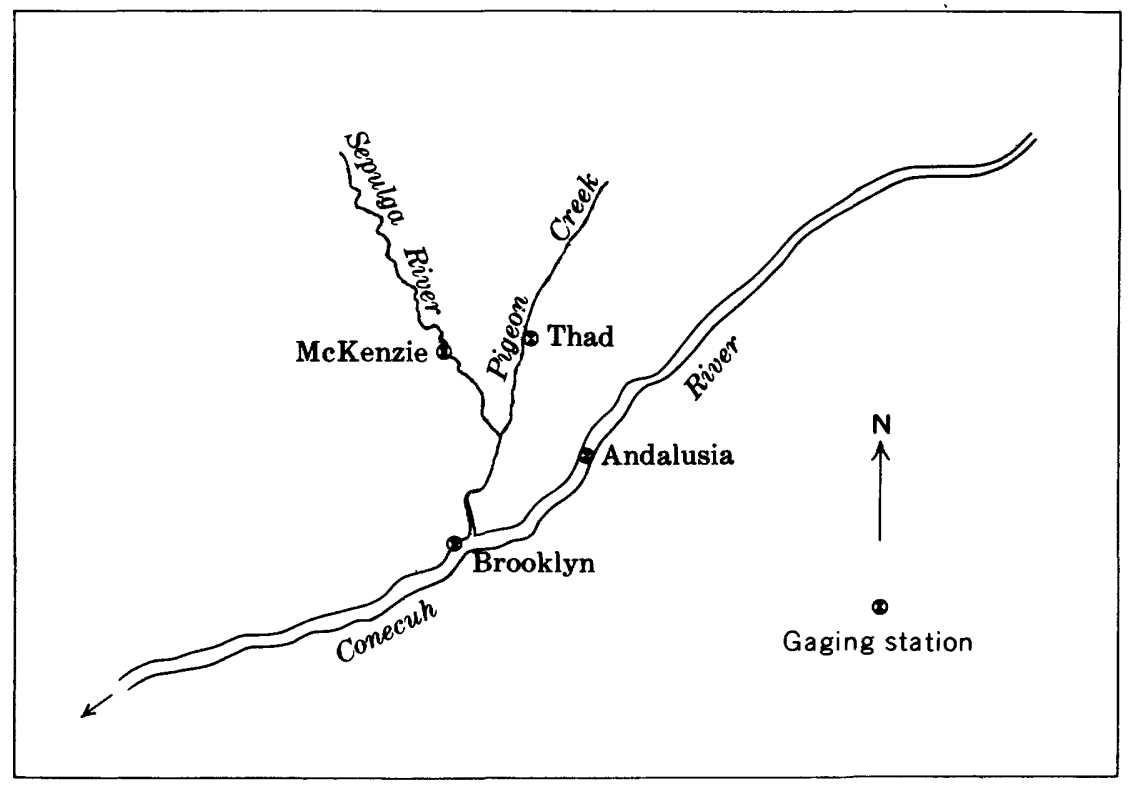

Figure 38.-Andalusia-Brooklyn reach on Conecuh River. 
vening inflow is ungaged and is classed as local inflow. The drainage areas for the various sources are:

Point

Drainage area (square miles)

Andalusia

296

McKenzie

Thad

Bocal...

DETERMINATION OF STORAGE

Records for the flood of March-April 1944 were used in computing storage. Local inflow was estimated on the basis of rainfall and runoff per square mile of other streams in the region. Since the streams rise fairly slowly, the time unit used was the day. In table 3 , the daily inflows at points in the reach are listed in columns $2,3,4$ and 5. The total daily inflow is listed in column 6 and the daily outflow at Brooklyn is listed in column 8 . The cumulative inflow and the cumulative outflow are listed in columns 7 and 9, respectively, and the difference in cumulative inflow and cumulative outflow, which is equal to the storage in the reach up to midnight of each indicated day, is listed in column 10 .

\section{DETERMTNATION OF CONSTANTS}

In table 4 , the total instantaneous inflow at 12 p.m. is listed in column 2 and the outflow discharge and total storage in the reach at 12 p.m. are listed in columns 3 and 4 . The weighted discharge for various assumed values of $x$ was computed by using equation (10) and is listed in columns 5 to 7 .

$$
\text { weighted discharge }=x I+(1-x) O
$$

The weighted discharge-storage plots are shown on figure 39 . The storage loop is closed and the relation best approximates a

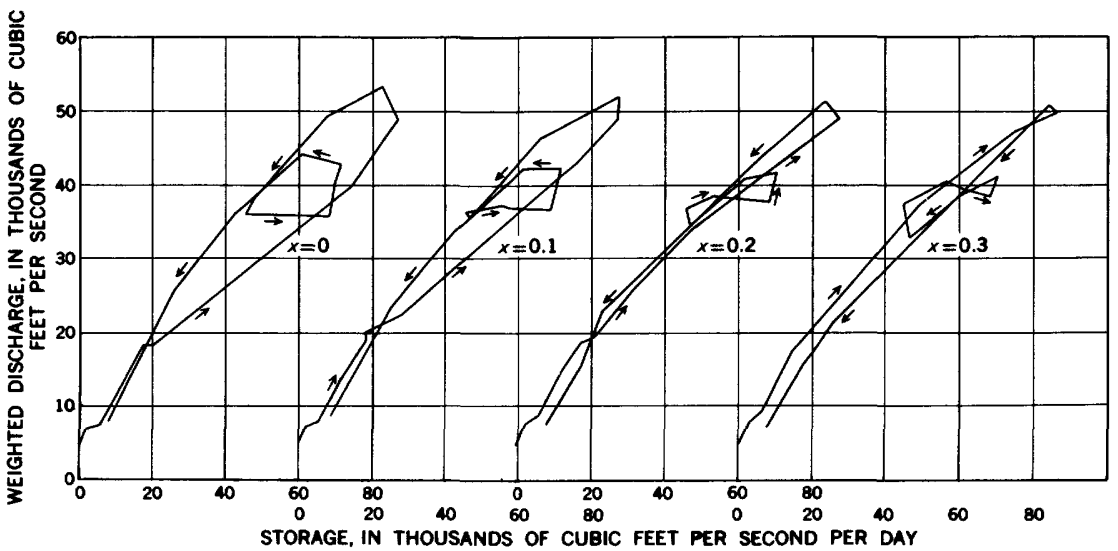

FIgURE 39.-Relation of storage to weighted discharge for different values of $x$. 
straight line when $x=0.2$. The average slope of the weighted discharge-storage relation is equal to $K$. On the graph for $x=0.2$ the slope averages about 2.0 days, hence, for the reach as a whole, $x=0.2$ and $K=2.0$ days.

TABLE 4.-Computation of weighting factor $x$ for Andalusia-Brooklyn reach, Conecuh River

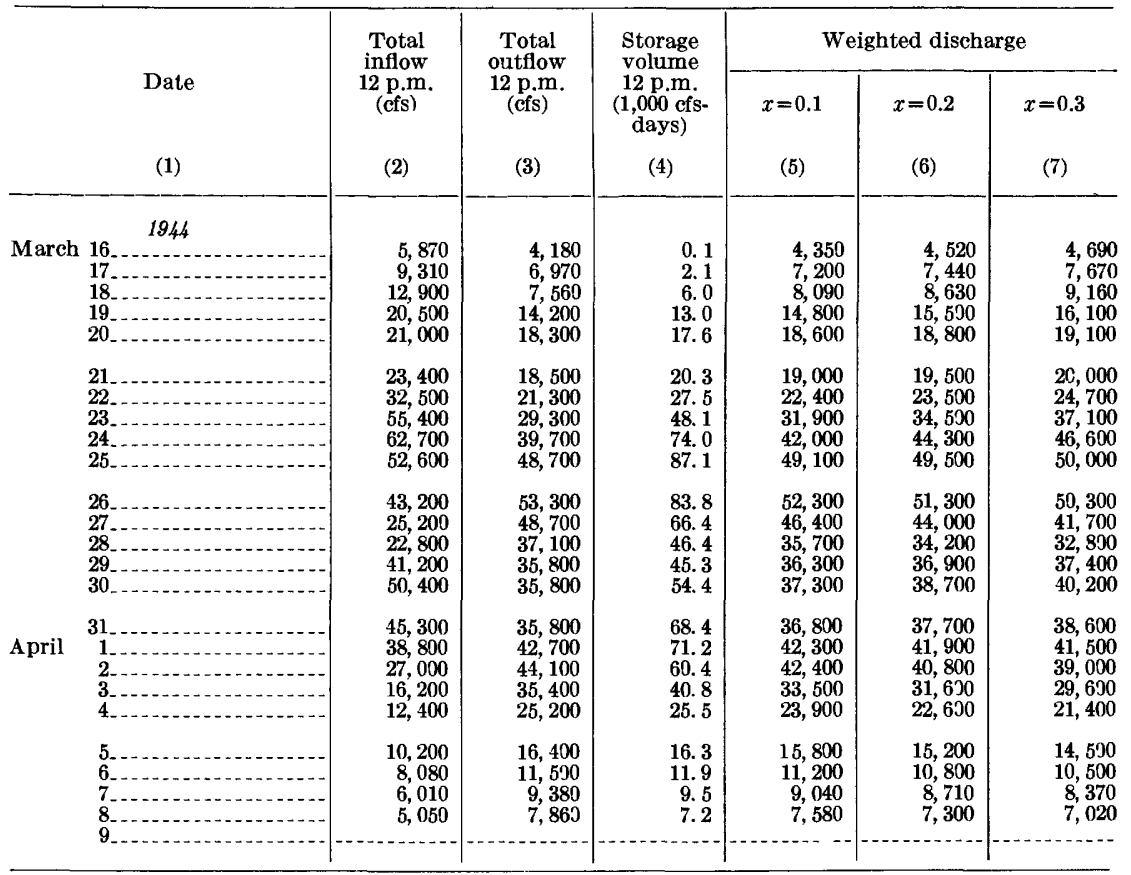

The inflow, which enters the reach at four places, necessitates the determination of a separate $K$ for each component inflow as is shown in the following table:

$K$ for each component inflow

[Equations 8 and 9 used]

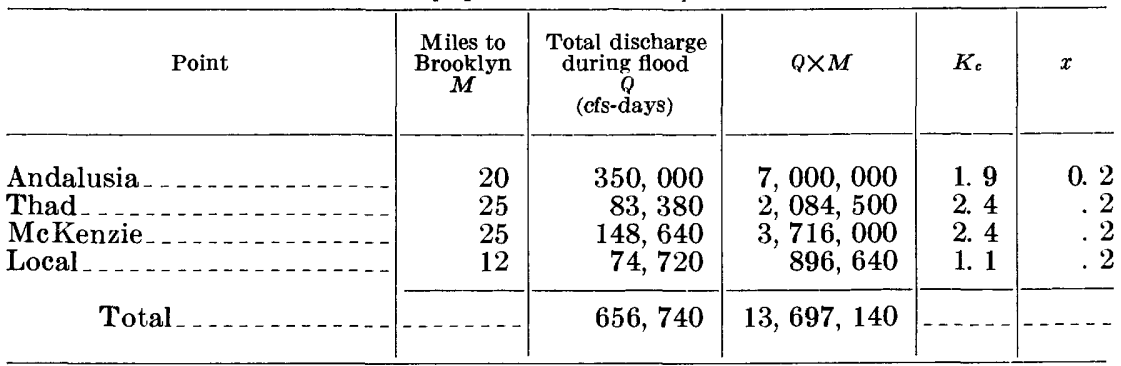

$$
\begin{gathered}
K_{m}-\frac{656,740}{13,697,140} \times 2.0=0.0959 \text { days per mile. } \\
K_{c}=M K_{m}
\end{gathered}
$$


From the value of $x$ and $K$ for each component of the inflow, the flood-routing coefficients for each inflow may be computed from equation (6).

To test the routing coefficients, the outflow hydrograph is computed from the record of inflow discharge. These computations, along with the routing coefficients used, are shown in table 5 . At the

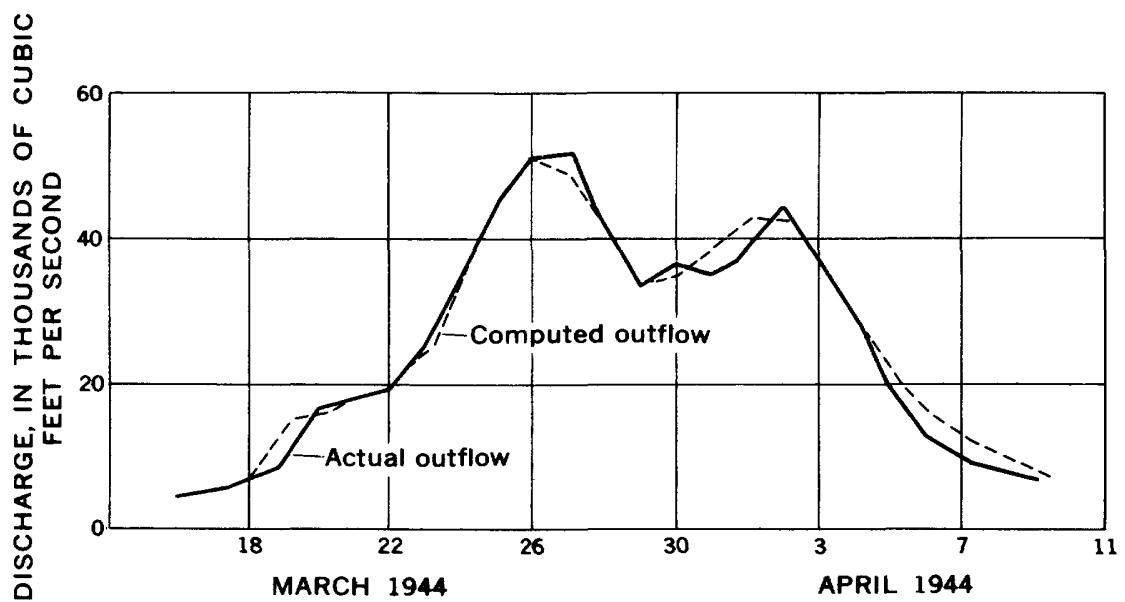

FIGURE 40.-Comparison of computed and actual hydrograph, Conemh River near Brooklyn, Ala.

beginning of the rise the inflow and outflow are assumed to be equal. Then, since $I_{1}, I_{2}$ and $O_{1}$ are known, $O_{2}$ may be computed from equation (7).

The total of the computed outflows is compared with the actual outflow on figure 40 .

The procedure used in testing the coefficients may be used also in routing other floods through the reach in either the upstream or downstream direction. 
STORAGE AND FLOOD ROUTING

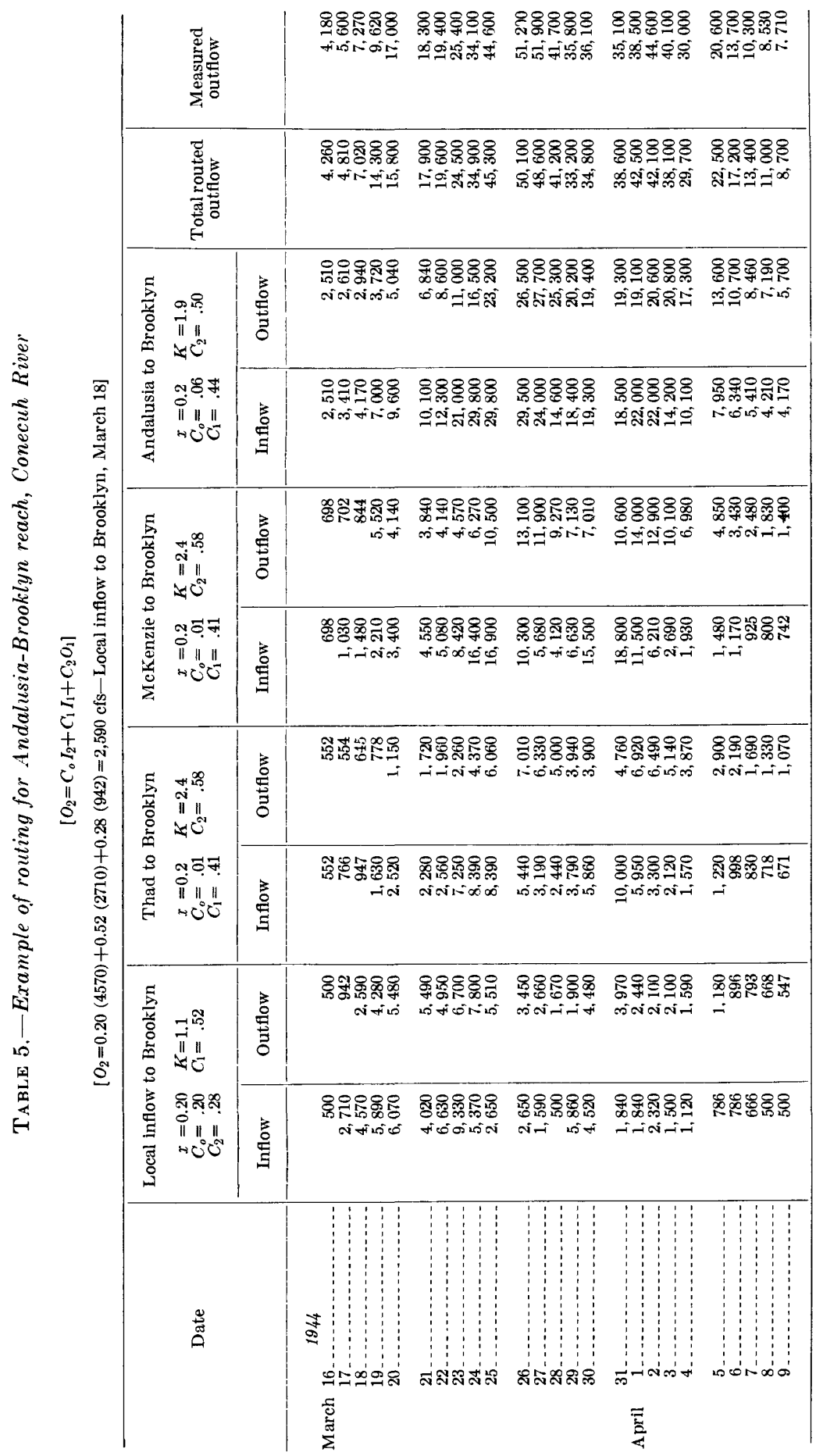




\section{RESERVOIR-STORAGE METHOD}

If the storage in a pond or reservoir can be related solely to the outflow discharge, as schematically shown in figure 31 , then the general equation (2) can be rearranged to permit rapid calculation of the outflow hydrograph.

$$
\left(I_{1}+I_{2}\right)+\frac{2 S_{1}}{\Delta t}-O_{1}=\frac{2 S_{2}}{\Delta t}+O_{2}
$$

The only data needed to use this method are the inflow hydrograph and the storage-outflow relation. The latter may be determined by combining the stage-outflow relation and the stage-storage relation. To use the method conveniently, values of $\frac{2 S}{\Delta t}+O$ are computed and plotted against corresponding values of $O$. Selected values are shown in table 6 to illustrate the computation.

$\mathrm{T}_{\mathrm{ABLE}}$ 6.-Selected values of $\frac{2 S}{\Delta t}+O$ for $\Delta t=15$ minutes

\begin{tabular}{|c|c|c|c|}
\hline Stage (feet) & $\begin{array}{c}\text { Storage } \\
\text { (cubic feet) }\end{array}$ & $\begin{array}{l}\text { Outflow dis- } \\
\text { charge (efs) }\end{array}$ & $\frac{2 S}{\Delta t}+O(\mathrm{css})$ \\
\hline $\begin{array}{l}10.29 \\
10.3 \\
10.4 \\
10.6 \\
10.8\end{array}$ & $\begin{array}{r}530 \\
535 \\
680 \\
1,050 \\
1,550\end{array}$ & $\begin{array}{l}0 \\
.01 \\
.32 \\
2.55 \\
7.50\end{array}$ & $\begin{array}{l}\text { 1. } 18 \\
\text { 1. } 20 \\
\text { 1. } 83 \\
\text { 4. } 88 \\
\text { 10. } 9\end{array}$ \\
\hline $\begin{array}{l}11.0 \\
11.2 \\
11.4 \\
11.6 \\
11.8\end{array}$ & $\begin{array}{l}2,240 \\
3,210 \\
4,580 \\
6,430 \\
8,800\end{array}$ & $\begin{array}{l}\text { 14. } 4 \\
21.6 \\
28.9 \\
36.3 \\
44.3\end{array}$ & $\begin{array}{l}\text { 19. } 4 \\
\text { 28. } 7 \\
\text { 39. } 1 \\
\text { 50. } 6 \\
\text { 63. } 9\end{array}$ \\
\hline $\begin{array}{l}12.0 \\
12.2 \\
12.4 \\
12.6\end{array}$ & $\begin{array}{l}11,900 \\
16,800 \\
23,400 \\
31,600 \\
41,800\end{array}$ & $\begin{array}{l}\text { 53. } 0 \\
62.0 \\
71.5 \\
81.5 \\
92.0\end{array}$ & $\begin{array}{l}79.4 \\
99.3 \\
123 \\
152 \\
185\end{array}$ \\
\hline $\begin{array}{l}13.0 \\
13.2 \\
13.4 \\
13.6 \\
13.8 \\
14.0\end{array}$ & $\begin{array}{r}53,600 \\
67,900 \\
86,200 \\
111,000 \\
143,000 \\
190,000\end{array}$ & $\begin{array}{l}103 \\
114 \\
126 \\
138 \\
150 \\
163\end{array}$ & $\begin{array}{l}222 \\
265 \\
318 \\
38.5 \\
468 \\
585\end{array}$ \\
\hline $\begin{array}{l}14.2 \\
14.4 \\
14.6 \\
14.8\end{array}$ & $\begin{array}{l}256,000 \\
352,000 \\
493,000 \\
658,000 \\
952,000\end{array}$ & $\begin{array}{l}177 \\
191 \\
205 \\
219 \\
233\end{array}$ & $\begin{array}{r}746 \\
973 \\
1,300 \\
1,680 \\
2,350\end{array}$ \\
\hline
\end{tabular}


A sample of the routing computations is given in table 7 . The computations begin at a known value of outflow and inflow. The steps then are as follows:

1. Entries in columns 1 and 2 are known. The first entry of outflow in column 5 is given.

2. Column 3 contains successive sums of values of inflow in column 2 for the particular time period under consideration and for the previous period.

3. Table 6 is entered with the known value of $O$, and the initial value of $\frac{2 S}{\Delta t}+O$ is selected for column 4 of table 7 .

4. From the value in column 4 subtract twice the value in column 5 and enter the result in column 6 .

5. Add the value in column 6 to the value in column 3 of the succeeding time period and enter the result in column 4 for the new time period under consideration.

6. The new outflow discharge in column 5 is again obtained from the relation of $\frac{2 S}{\Delta t}+O$ with $O$ in table 6 .

7. The steps 4,5 , and 6 are then repeated until the entire outflow hydrograph is generated.

8. The stage corresponding to this outflow is then selected from table 6 and entered in column 7 of table 7.

TABLE 7.-Routing through a reservoir

\begin{tabular}{|c|c|c|c|c|c|c|}
\hline Time & $\underset{\text { efs }}{\text { Inflow }}$ & $I_{1}+I_{2}$ & $\frac{2 S}{\Delta t}+o$ & $\begin{array}{l}\text { Outflow } \\
\text { efs }\end{array}$ & $\frac{2 S}{\Delta t}-0$ & $\begin{array}{c}\text { Gage } \\
\text { height } \\
\text { (feet) }\end{array}$ \\
\hline (1) & (2) & (3) & (4) & (5) & (6) & (7) \\
\hline $\begin{array}{r}0: 00 \\
15 \\
: 30 \\
: 45 \\
1: 00\end{array}$ & $\begin{array}{r}0 \\
1.44 \\
4.34 \\
8.90 \\
18.7\end{array}$ & $\begin{array}{c}0 \\
1.44 \\
5.78 \\
13.24 \\
27.6\end{array}$ & $\begin{array}{r}1.18 \\
2.62 \\
6.72 \\
11.88 \\
22.9\end{array}$ & $\begin{array}{r}0 \\
.84 \\
4.04 \\
8.30 \\
17.2\end{array}$ & $\begin{array}{r}1.18 \\
-1.34 \\
-4.72 \\
-11.5\end{array}$ & $\begin{array}{l}10.29 \\
10.47 \\
10.67 \\
10.82 \\
11.08\end{array}$ \\
\hline $\begin{array}{l}1: 15 \ldots \ldots \ldots \\
1: 30 \ldots \ldots \\
1: 45 \ldots \\
2: 00 \\
2: 15\end{array}$ & $\begin{array}{l}38.8 \\
106 \\
216 \\
291 \\
320\end{array}$ & $\begin{array}{l}57.5 \\
144.8 \\
322 \\
507 \\
611\end{array}$ & $\begin{array}{l}46.0 \\
123.8 \\
303 \\
584 \\
853\end{array}$ & $\begin{array}{l}33.5 \\
71.6 \\
123 \\
161 \\
185\end{array}$ & $\begin{array}{c}-21.0 \\
-19.4 \\
57 \\
242 \\
483\end{array}$ & $\begin{array}{l}\text { 11. } 52 \\
\text { 12. } 40 \\
\text { 13. } 35 \\
\text { 13. } 97 \\
\text { 14. } 31\end{array}$ \\
\hline $\begin{array}{l}2: 30 \\
2: 45 \\
3: 00 \\
3: 15 \\
3: 30\end{array}$ & $\begin{array}{l}325 \\
309 \\
285 \\
260 \\
235\end{array}$ & $\begin{array}{l}645 \\
634 \\
594 \\
545 \\
495\end{array}$ & $\begin{array}{l}1,128 \\
1,366 \\
1,544 \\
1,661 \\
1,718\end{array}$ & $\begin{array}{l}198 \\
208 \\
214 \\
219 \\
220\end{array}$ & $\begin{array}{r}732 \\
950 \\
1,116 \\
1,223 \\
1,278\end{array}$ & $\begin{array}{l}14.50 \\
14.64 \\
14.73 \\
14.80 \\
14.81\end{array}$ \\
\hline $\begin{array}{l}3: 45 \\
4: 00 \\
4: 15 \\
4: 30 \\
4: 45\end{array}$ & $\begin{array}{l}211 \\
188 \\
165 \\
145 \\
129\end{array}$ & $\begin{array}{l}446 \\
399 \\
353 \\
310 \\
274\end{array}$ & $\begin{array}{l}1,724 \\
1,683 \\
1,598 \\
1,474 \\
1,324\end{array}$ & $\begin{array}{l}220 \\
219 \\
217 \\
212 \\
206\end{array}$ & $\begin{array}{l}1,284 \\
1,245 \\
1,164 \\
1,050 \\
912\end{array}$ & $\begin{array}{l}14.81 \\
14.80 \\
14.77 \\
14.70 \\
14.61\end{array}$ \\
\hline $\begin{array}{l}5: 00 \\
5: 15 \\
5: 30 \\
5: 45 \\
6: 00\end{array}$ & $\begin{array}{l}116 \\
106 \\
96.4 \\
88.0 \\
80.2\end{array}$ & $\begin{array}{l}246 \\
2222 \\
202.4 \\
184.4 \\
168.2\end{array}$ & $\begin{array}{l}1,158 \\
982 \\
802.4 \\
624.8 \\
461.0\end{array}$ & $\begin{array}{l}199 \\
191 \\
181 \\
166 \\
149\end{array}$ & $\begin{array}{l}760 \\
600 \\
440.4 \\
292.8 \\
163.0\end{array}$ & $\begin{array}{l}14.51 \\
14.40 \\
14.26 \\
14.04 \\
13.78\end{array}$ \\
\hline $\begin{array}{l}\text { 15:00 } \\
\text { 15:15 } 30 \\
\text { 15:45 } 00 \text { Total }\end{array}$ & $\begin{array}{r}0.75 \\
.47 \\
.22 \\
0 \\
0 \\
4,504\end{array}$ & $\begin{array}{r}1.82 \\
1.22 \\
.69 \\
.22 \\
0\end{array}$ & $\begin{array}{l}2.61 \\
2.17 \\
1.78 \\
1.40 \\
1.18\end{array}$ & $\begin{array}{r}.83 \\
.54 \\
.30 \\
.11 \\
0 \\
4,504\end{array}$ & $\begin{array}{l}.95 \\
1.09 \\
1.18 \\
1.18\end{array}$ & $\begin{array}{l}10.47 \\
10.43 \\
10.39 \\
10.33 \\
10.29\end{array}$ \\
\hline
\end{tabular}


The relation $\frac{2 S}{\Delta t}+O$ versus $O$ may be used in either a graphic or a tabular form. If a number of peaks are to be routed through the reservoir, the tabular form is more convenient because machine computation can be more readily utilized.

In table 7 the computations are shown only for the first 6 hours and the final hour. Figure 41 is a plot of the entire inflow and

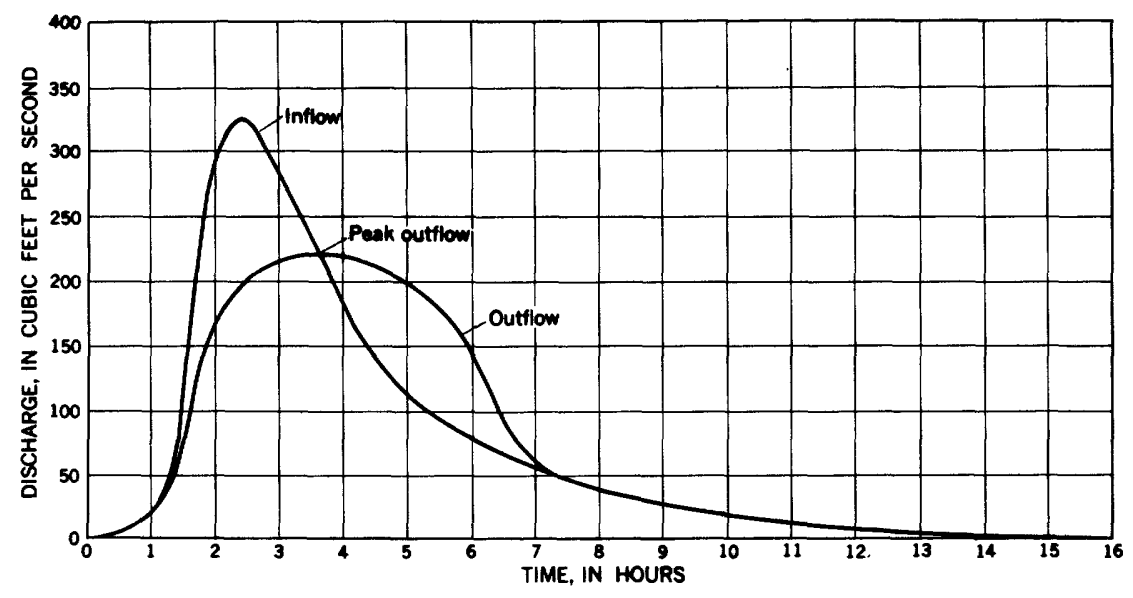

Figure 41.-Inflow and outflow hydrographs for reservoir.

outflow hydrographs. The sums of the ordinates of the two hydrographs, at the bottom of table 7 , are equal.

The method can be used also to determine the inflow hydrograph if the outflow hydrograph is known.

\section{SELECTED REFERENCES}

Kinnison, H. B., Conover, L. F., and Bigwood, B. L., 1938, Stages and flood discharges of the Connecticut River at Hartford, Conn.: U.S. Geol. Survey Water-Supply Paper 836-A, p. 1-18.

Langbein, W. B., 1940, Channel storage and unit hydrograph studies: Am. Geophys. Union Trans., pt. 2, p. 620-627.

Myer, O. H., 1941, Flood routing on Sacramento River: Am. Geophys. Union Trans., pt. 1, p. 118-124.

Rutter, E. J., Graves, Q. B., and Snyder, F. F., 1939, Flood routing: Am. Soc. Civil Engineers Trans., v. 104, p. 275-294.

Johnstone, Don, and Cross, W. P., 1949, Elements of applied hydrology: New York, Ronald Press Co., 276 p.

U. S. Department of the Army, Corps of Engineers 1953, Routing of flood through river channels: Eng. Manual, pt. 114, chap. 8.

U. S. Geological Survey, 1952, Kansas-Missouri floods of July 1951: U.S. Geol. Survey Water-Supply Paper 1139, 239 p. 